\title{
Aberrant Formation of Glutamate Receptor Complexes in Hippocampal Neurons of Mice Lacking the GluR2 AMPA Receptor Subunit
}

\author{
Nathalie Sans, ${ }^{1}$ Bryce Vissel,,${ }^{2,3}$ Ronald S. Petralia, ${ }^{1}$ Ya-Xian Wang, ${ }^{1}$ Kai Chang, ${ }^{1}$ Gordon A. Royle, ${ }^{2}$ Chang-Yu Wang, ${ }^{1}$ \\ Steve $0^{\prime}$ Gorman, ${ }^{2}$ Stephen F. Heinemann, ${ }^{2}$ and Robert J. Wenthold ${ }^{1}$ \\ ${ }^{1}$ Laboratory of Neurochemistry, National Institute on Deafness and Other Communication Disorders, National Institutes of Health, Bethesda, Maryland \\ 20892-8027, ${ }^{2}$ Molecular Neurobiology Laboratory, The Salk Institute for Biological Studies, La Jolla, California 92037, and ${ }^{3}$ Garvan Institute of Medical \\ Research, Darlinghurst NSW 2010, Australia
}

The number and type of receptors present at the postsynaptic membrane determine the response to the neurotransmitter released from the presynaptic terminal. Because most neurons receive multiple and distinct synaptic inputs and contain several different subtypes of receptors stimulated by the same neurotransmitter, the assembly and trafficking of receptors in neurons is a complex process involving many levels of regulation. To investigate the mechanism that neurons use to regulate the assembly of receptor subunits, we studied a GluR2 knock-out mouse. GluR2 is a critical subunit that controls calcium permeability of AMPA receptors and is present in most native AMPA receptors. Our data indicate that in the absence of GluR2, aberrant receptor complexes composed of GluR1 and GluR3 are formed in the hippocampus, and that there is an increased number of homomeric GluR1 and GluR3 receptors. We also show that these homomeric and heteromeric receptors are less efficiently expressed at the synapse. Our results show that GluR2 plays a critical role in controlling the assembly of AMPA receptors, and that the assembly of subunits may reflect the affinity of one subunit for another or the stability of intermediates in the assembly process. Therefore, GluR1 may have a greater preference for GluR2 than it does for GluR3.

Key words: AMPA receptors; assembly; GluR2 knock-out mouse; hippocampus; glutamate receptors; immunoprecipitation

\section{Introduction}

The AMPA subtype of ionotropic glutamate receptors (AMPAR) mediates most excitatory neurotransmission in the CNS and is made up of four subunits, GluR1-R4 (also referred to as GluRA-D) (Hollmann and Heinemann, 1994; Dingledine et al., 1999), that assemble into a tetrameric complex to form a functional ion channel that is permeable to $\mathrm{Na}^{+}$and $\mathrm{K}^{+}$ions (Mano and Teichberg, 1998; Rosenmund et al., 1998; Mansour et al., 2001). The functional properties of the receptor depend on the composition of subunits that make up the complex, with GluR2 being a key subunit that determines the impermeability to $\mathrm{Ca}^{2+}$ (Tanaka et al., 2000).

Functional receptors can be generated from identical subunits to form a homomeric complex or from mixed subunits to form a heteromeric complex. Although initial expression studies implied that heteromeric receptors could be formed from a combination of all four subunits, recent studies suggest that a maxi-

\footnotetext{
Received June 19, 2003; revised Aug. 27, 2003; accepted Aug. 29, 2003.

This work was supported by National Institute on Deafness and Other Communication Disorders-National Institutes of Health Medical Research Council Grant 188819 and Hereditary Disease Foundation Lieberman Award to B.V. We thank Dr. Konrad Noben-Trauth, C. Melissa Irby, and Jimmy Fiallos for technical help with maintaining the colony of GluR2 mice, Marsha Tsay for technical assistance, and Dr. J. Morrison for providing the GluR3 monoclonal antibody. We also thank Drs. K. Iwasa and M. Montcouquiol for helpful comments and discussion.

Correspondence should be addressed to Dr. Nathalie Sans, National Institute on Deafness and Other Communication Disorders-National Institutes of Health, Building 50, Room 4146, Bethesda, MD 20892-8027. E-mail: sansn@nidcd.nih.gov.

Copyright $\odot 2003$ Society for Neuroscience $\quad$ 0270-6474/03/239367-07\$15.00/0
}

mum of two different subunits is present in a tetrameric complex (Ayalon and Stern-Bach, 2001; Mansour et al., 2001). AMPAR complexes in pyramidal neurons of the adult hippocampus are made of two types, those containing GluR1 and GluR2 and those containing GluR2 and GluR3, with a small population of homomeric GluR1 receptors (Wenthold et al., 1996). The relative amounts of these two classes of heteromeric receptors available for addition to the synapse could directly affect the number and functional properties of the synaptic AMPARs. Therefore, subunit assembly may represent a critical step in the regulation of AMPARs, and the mechanism by which two populations of receptors are generated in the same neuron is an interesting and fundamentally important question. The functional significance of the two major populations of AMPARs in hippocampal pyramidal neurons was demonstrated by Shi et al. (1999), who showed that GluR1-R2 receptors are added to the synapse in an activity-dependent manner, whereas GluR2-R3 receptors are constitutively added (for review, see Malinow et al., 2000; Malinow and Malenka, 2002). These differences in the trafficking of two classes of heteromeric receptors may be explained by the length and sequence divergence in the $\mathrm{C}$ termini of the subunits. GluR1 has a type-I PDZ [postsynaptic density-95 (PSD-95)/Discs large (Dlg)/zona occludens-1 (ZO-1)]-binding site (-ATGL) at its extreme $\mathrm{C}$ terminus and has been shown to interact with synapse-associated protein-97 (SAP97), whereas GluR2 and GluR3 have a type-II PDZ-binding site (-SVKI) at their extreme 
Table 1. Quantification of immunogold localization of AMPA receptors in the CA1 stratum radiatum

\begin{tabular}{|c|c|c|c|}
\hline Antibody & Animal & CA1-stratum radiatum gold per synapse & Number of synapses \\
\hline \multirow[t]{2}{*}{ GluR2 gold per synapse } & WT ( 2 animals; 2 experiments using 1 antibody) & 0.13 & 480 \\
\hline & KO (2 animals; 2 experiments using 1 antibody) & 0.005 & 372 \\
\hline \multirow[t]{2}{*}{ GluR2/3 gold per synapse } & WT ( 2 animals; 4 experiments using 1 antibody) & 1.23 & 860 \\
\hline & KO (2 animals; 4 experiments using 1 antibody) & 0.18 & 856 \\
\hline \multirow[t]{2}{*}{ GluR3 1/100 gold per synapse } & WT 2 animals & 0.25 & 460 \\
\hline & KO 2 animals & 0.18 & 385 \\
\hline \multirow[t]{2}{*}{ GluR3 1/25 gold per synapse } & WT 2 animals & 0.55 & 379 \\
\hline & KO 2 animals & 0.41 & 339 \\
\hline \multirow[t]{2}{*}{ GluR1 gold per synapse } & WT (3 animals; 7 experiments using 2 antibodies) & 0.55 & 1346 \\
\hline & KO (3 animals; 7 experiments using 2 antibodies) & 0.31 & 1324 \\
\hline \multirow[t]{2}{*}{ GluR1 gold per micrometer } & WT (3 animals; 3 experiments using 2 antibodies) & 3.5 & 641 \\
\hline & KO ( 3 animals; 3 experiments using 2 antibodies) & 2.2 & 664 \\
\hline \multirow[t]{2}{*}{ Control } & WT (1 animal; 1 experiment using 1 antibody) & 0 & 117 \\
\hline & KO (1 animal; 1 experiment using 1 antibody) & 0 & 109 \\
\hline
\end{tabular}

All differences between WT (GluR2 ${ }^{+/+}$) and KO (GluR2 ${ }^{-/-}$) are highly significant, except for GluR3, for which the decreases in K0s are slightly significant $(p<0.05$ for $1 / 100 ; p<0.02$ for $1 / 25)$. Average synapse length for GluR1-labeled sections is $0.20 \mu \mathrm{m}(n=641)$ and $0.19 \mu \mathrm{m}(n=664)$ for WT and KO, respectively. This $5 \%$ decrease in length is significant. For the latter study, the same area of neuropil was examined ( $\left.>2000 \mu \mathrm{m}^{2}\right)$ for WT and K0, although the area contributed by large structures, especially dendrites, was not subtracted. This indicates that there are, at most, only small changes in synapse number and length.

C terminus and interact via this motif to numerous PDZ proteins such as GRIP (glutamate receptor-interacting protein), ABP (AMPA-binding protein), and PICK-1 (PKC-interacting protein) (Henley, 2003). These proteins have been implicated in the clustering of AMPARs or their turnover, whereas SAP97 may be a critical molecule involved in the synaptic delivery of GluR1containing receptors. In addition, GluR2 specifically binds to NSF ( $N$-ethylmaleimide-sensitive factor), a chaperone protein implicated in SNARE (soluble $N$-ethylmaleimide-sensitive factor attached protein receptor) complex disassembly (Henley, 2003).

In the present study, we hypothesized that GluR2 plays a critical role in assembly of AMPAR by being the preferred partner for both GluR1 and GluR3, such that GluR1-R3 complexes are not formed in the presence of sufficient GluR2. We tested this hypothesis by characterizing the assembly of AMPAR subunits in the hippocampus of mice with reduced or deleted GluR2. Our results point to a critical role of GluR2 in both subunit assembly and the synaptic expression of the receptor complex.

\section{Materials and Methods}

Generation of a GluR2 knock-out mouse. Animals were handled in accordance with the National Institutes of Health Guide for the Care and Use of Laboratory Animals. The targeting construct was generated from DNA cloned from a 129 SvEv DNA genomic library. In this construct, a neomycin gene (Neo) was placed downstream of exon 11, which encodes membrane domain 1 and 2 of GluR2 (Hollmann and Heinemann, 1994). Exon 11 and the neomycin gene were surrounded by loxP sites. The construct was electroporated into CCE embryonic stem (ES) cells, which are derived from 129SvEv mice (Robertson, 1987). Colonies resistant to G418 were isolated, grown, and analyzed by Southern blot analysis. An ES cell colony that contained the allele shown in Figure 1 AI was identified. This ES cell colony was electroporated with a cAMP response element (Cre)-expressing plasmid and then replated in the absence of G418. Cre recombinase recombines between loxP sites, excising exon 11 and the neomycin gene, producing a knock-out of GluR2. Therefore, ES cell colonies that contained the allele shown in Figure 1 AII were chosen for blastocyst injection. Electroporation with targeting vectors and the Creexpressing plasmid pOG231 was done as detailed previously (O'Gorman et al., 1997).

Antibodies. The following primary antibodies were used for immunoprecipitation (IP), immunoblotting, and immunocytochemistry: rabbit polyclonals directed against the C terminus of GluR1, GluR2/3, GluR3, GluR4 (Wenthold et al., 1992), and GluR2 (Petralia et al., 1997); mouse monoclonals directed against the $\mathrm{N}$ terminus of GluR2 (Chemicon, Temecula, CA) and GluR3 (Moga et al., 2003).

Preparation of tissue extracts. For each set of experiments, three or more hippocampi from mice of each genotype, GluR2 ${ }^{+/+}$, GluR2 ${ }^{+/-}$, and GluR2 ${ }^{-1-}$, were pooled and homogenized in PBS containing a mixture of protease inhibitors (Sans et al., 2000). Protein concentrations were measured using a BCA assay (Pierce, Rockford, IL) or a Bio-Rad protein assay (Bio-Rad, Hercules, CA).

Immunoprecipitation. IP experiments were performed after Triton X-100 solubilization as described previously (Wenthold et al., 1996; Sans et al., 2001). Briefly, hippocampi from adult GluR2 ${ }^{+/+}, \mathrm{GluR} 2^{+/-}$, and GluR2 ${ }^{-1-}$ mice were homogenized with a polytron in $50 \mathrm{~mm}$ Tris- $\mathrm{HCl}$, $\mathrm{pH} 7.4$, containing a protease inhibitor mixture (Roche Products, Indianapolis, IN). Membranes were sedimented by centrifugation $\left(100,000 \times g ; 30 \mathrm{~min} ; 4^{\circ} \mathrm{C}\right)$, solubilized in $1 \%$ Triton X-100, $50 \mathrm{~mm}$ Tris- $\mathrm{HCl}, 1 \mathrm{~mm}$ EDTA, pH 7.4, for $30-45 \mathrm{~min}$ at $37^{\circ} \mathrm{C}$, and insoluble material was removed by centrifugation. For immunoprecipitation, 10 $\mu \mathrm{g}$ of polyclonal antibodies (GluR1, GluR2/3, GluR4, GluR1 plus GluR2-R3, GluR1 plus GluR4, and GluR2/3 plus GluR4) were attached to protein-A beads. Protein-A beads were then pelleted, washed in PBS plus $0.1 \%$ Triton X-100, and incubated with $0.5 \mathrm{ml}$ of the Triton X-100solubilized tissue at $4^{\circ} \mathrm{C}$ with constant rotation. The beads were then washed with $50 \mathrm{~mm}$ Tris- $\mathrm{HCl}, \mathrm{pH} 7.5$, containing $0.1 \%$ Triton X-100 and $150 \mathrm{~mm} \mathrm{NaCl}$, and processed as described by Sans et al. (2001).

SDS-PAGE and immunoblot analysis. Proteins were separated with SDS-PAGE ( 8 or $4-20 \%$ gradient gels) and transferred to Immobilon-P membranes and treated as described previously (Sans et al., 2001). The following antibodies were used for immunoblotting: polyclonal GluR1 $(0.5 \mu \mathrm{g} / \mathrm{ml})$, polyclonal GluR2/3 $(0.15 \mu \mathrm{g} / \mathrm{ml})$, polyclonal GluR2 $(0.5$ $\mu \mathrm{g} / \mathrm{ml})$, polyclonal GluR3 $(2.0 \mu \mathrm{g} / \mathrm{ml})$, polyclonal GluR4 $(1.0 \mu \mathrm{g} / \mathrm{ml})$, and monoclonal GluR2 (1/500) or monoclonal GluR3 $(3.0 \mu \mathrm{g} / \mathrm{ml})$. After chemiluminescence detection, films were scanned using a Molecular Dynamics (Sunnyvale, CA) densitometer. The quantifications were performed as described previously (Wenthold et al., 1996; Sans et al., 2001).

Deglycosylation. Membrane homogenates were resuspended in denaturing buffer (10 $\mathrm{mm} \mathrm{NaH}_{2} \mathrm{PO}_{4}, \mathrm{pH} 6,0.5 \%$ SDS, $2 \%$ glycerol, $1 \%$ $\beta$-mercaptoethanol), incubated for $3 \mathrm{~min}$ at $100^{\circ} \mathrm{C}$, and diluted with $1 \%$ Nonidet $\mathrm{P} 40$ in $10 \mathrm{~mm} \mathrm{NaH}_{2} \mathrm{PO}_{4}, \mathrm{pH}$ 6, containing the above protease mixture and incubated with Endo $\mathrm{H}$ ( $15 \mathrm{mU}$ ) or PNGaseF (3 U) for $4 \mathrm{hr}$ at $37^{\circ} \mathrm{C}$. The resulting material was diluted with $5 \times$ sample buffer and subjected to SDS-PAGE on $8 \%$ acrylamide gels.

Immunocytochemistry. Postembedding immunogold was performed as described previously (Sans et al., 2000, 2001). Thin sections were immunogold labeled with $10 \mathrm{~nm}$ of gold for single labeling. For double labeling, the two primary antibodies (rabbit and mouse) were combined, and the two secondary antibodies (5 plus $10 \mathrm{~nm}$ of gold) were combined. Quantification of gold was performed on randomly selected areas as described previously. Two or three animals were used for both GluR2 $2^{+/+}$ and GluR2 ${ }^{-1-}$ (synapses, cell bodies); one animal was used for GluR4, the control (no primary antibody), and GluR1-labeled dendrites. Both 
spine and dendrite-shaft synapses were included in the counts in Table 1, although nearly all of these were spine synapses. Reduction of labeling for GluR2/3, GluR3, or GluR1 in the GluR2 ${ }^{-1-}$ to 15,73 (72\% for $1 / 100$; $75 \%$ for $1 / 25$ ), or $56 \%$, respectively, of the GluR $2^{+/+}$for all synapses, as noted in Results, was similar (12, 73, or 55\%, respectively) when dendrite shaft synapses were excluded. Brightness and contrast of micrographs were modified using Adobe Photoshop (Adobe Systems, San Jose, CA).

\section{Results}

\section{Knock-out of the GluR2 gene}

Chimeric mice from ES cell clones that transmitted the mutant allele to their offspring and were judged by Southern blot analysis of the GluR2 genomic locus, were bred with wild-type c57bl6 mice. Offspring mice that were heterozygous for the desired allele were then bred together, producing wild-type $\left(\mathrm{GluR} 2^{+/+}\right)$, heterozygous (GluR2 $2^{+/-}$), and mutant $\left(\mathrm{GluR}^{-/-}\right)$mice used in these studies. The mice were characterized by Southern blot (Fig. $1 B$ ), RNase protection assay (Fig. $1 C$ ), and immunoblot (Fig. $1 D$ ) analysis to demonstrate that the expected allele was included and that there was no expression of the GluR2 allele in the mutant GluR2 ${ }^{-/-}$mice. Western blot analysis of hippocampus proteins was also performed to measure the levels of the remaining AMPAR subunits (Fig. 1D). As reported previously (Jia et al., 1996), all four AMPAR subunits were present in the adult hippocampus, although the staining with antibodies to GluR4 was light, which is consistent with this subunit being present in low amounts (Wenthold et al., 1996). Our analyses showed a $51 \pm 6 \%$ decrease of GluR2 in the GluR2 ${ }^{+/-}$mice compared with the GluR2 ${ }^{+/+}$, and no detectable GluR2 was present in the GluR2 $^{-/-}$mice [using an N-terminal (data not shown) or C-terminal antibody]. The levels of GluR1, GluR3, and GluR4 were not significantly different in the GluR2 genotype $+/+$, $+/-$, and $-/-$ mice.

\section{AMPAR complexes in the absence of GluR2}

We used immunoprecipitation with subunit-specific antibodies to determine the subunit composition of Triton X-100solubilized AMPARs in GluR2 ${ }^{+/+}, \mathrm{GluR}^{+/-}$, and GluR2 ${ }^{-/-}$ mice as described previously (Wenthold et al., 1996). As shown previously in rats (Wenthold et al., 1996), Triton X-100 solubilization leads to a $75-85 \%$ solubilization of the AMPAR in mice (data not shown). No differences in solubilization were found among GluR2 ${ }^{+/+}$, GluR2 ${ }^{+/-}$, and GluR2 ${ }^{-/-}$mice (data not shown). Under the conditions used, the immunoprecipitation of GluR1, GluR2-R3, and GluR4 was complete after two rounds of immunoprecipitation. In the GluR2 ${ }^{+/+}$mice, immunoprecipitation with GluR1 antibodies coimmunoprecipitated mostly GluR2, to a lesser extent GluR4, but no detectable GluR3, showing that GluR1 does not form a complex with GluR3 in the GluR2 ${ }^{+/+}$hippocampus (Fig. 2). The GluR2/3 antibodies coimmunoprecipitated GluR1, GluR2, GluR3, and GluR4. These results are consistent with the findings of Wenthold et al. (1996) on the rat hippocampus. In the heterozygote GluR2 ${ }^{+/-}$mice, results similar to those seen for the wild type were obtained, except GluR1 now coimmunoprecipitated GluR3 (Fig. 2). The amount of coimmunoprecipitating GluR3 was greater in the GluR2 ${ }^{-1-}$ mouse than in the GluR2 ${ }^{+/-}$mouse, suggesting that formation of the GluR1-R3 complex is inversely related to the amount of GluR2 available. The results showing the formation of GluR1-R3 also rule out the trivial explanation for the presence of GluR1-R2 and GluR2/3 complexes that GluR1 and GluR3 are present in different populations of neurons.

To further analyze the composition of the receptor, we quan-
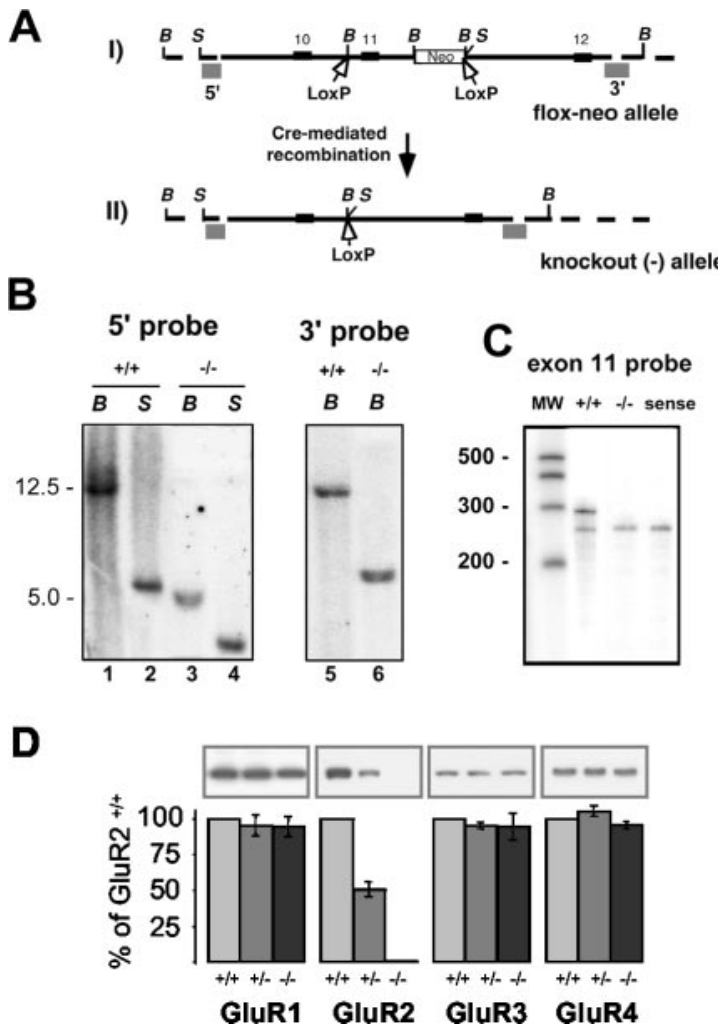

Figure 1. Generation and analysis of a GluR2 knock-out mouse. A, I, Allele generated by homologous recombination of the GluR2-targeting construct, showing the loxP sites that surround exon 11 and Neo inserted in the intron between exons 11 and 12. Exons 10, 11, and 12 are also shown. II, LoxP sites are indicated by open arrows; these contain BamHI restriction sites in the loxP cassette. 5' and 3' probes used for Southern blotting are shown as gray shaded boxes. B, BamHI; S, Spel. B, Southern blots demonstrating successful insertion of the construct at the targeted site. A $12.5 \mathrm{~Kb} \mathrm{BamHI}$ fragment and $5.5 \mathrm{~Kb}$ Spel fragment are seen in the wild-type mouse with the $5^{\prime}$ probe (lanes 1,2). Excision of the floxed fragment in the knock-out ( - ) allele moves the Spel site closer to the $5^{\prime}$ probe, resulting in a $3.5 \mathrm{~Kb}$ fragment (lane 4). Insertion of the IoxP cassette BamHI restriction site shortens the BamHI fragment seen by the $3^{\prime}$ probe to $6 \mathrm{~Kb}$ in the knock-out allele (lane 6). C, RNase protection assay for exon 11 of the GluR2 allele, demonstrating loss of expression of the GluR2-deleted region in the global knock-out animal ( $-/-)$ and normal expression in wild-type $(+/+)$ animals. Sense probe control is included (sense). RNA extracted from whole brains is shown. D, Hippocampus proteins from GluR2 ${ }^{+/+}$, GluR2 ${ }^{+/-}$, and GluR2 ${ }^{-1-}$ mice (10 $\mu \mathrm{g}$ per lane) were analyzed by SDS-PAGE and immunoblotted with the $C$ terminus polyclonal antibody indicated. Samples analyzed with different antibodies were obtained from the same preparation of the hippocampus. Histograms show the relative average amount of protein (percentage of $\mathrm{GluR2} 2^{+/+}$) of three sets of experiments. Levels were measured by densitometric scanning of Western blots.

tified the unbound fraction of the same immunoprecipitation experiments. Immunoprecipitation with GluR1 or GluR2/3 antibodies removed all corresponding subunits in the unbound fraction of GluR2 ${ }^{+/+}$, GluR2 ${ }^{+/-}$, and GluR2 $2^{-/-}$mice (Fig. 3). In the GluR2 ${ }^{+/+}$mice, immunoprecipitation with anti-GluR1 antibodies removed very little GluR3 (91\% remaining). With the reduction in GluR2, the amount of unbound GluR3 decreased to $70 \%$ in GluR2 ${ }^{+/-}$mice and $26 \%$ in GluR2 ${ }^{-/-}$mice. Therefore, decreased expression of GluR2 results in a change in GluR3 from very little associated with GluR1 in the GluR2 $2^{+1+}$ mice to most associated with GluR1 in the GluR2 ${ }^{-/-}$mice. Although an antibody that effectively immunoprecipitates GluR3 is not available, in the homozygous mouse, the GluR2/3 antibody can be used to immunoprecipitate GluR3. Under these conditions, a relatively large amount of GluR1 (56\%) is unbound with only a small amount associated with GluR4, indicating that approximately 


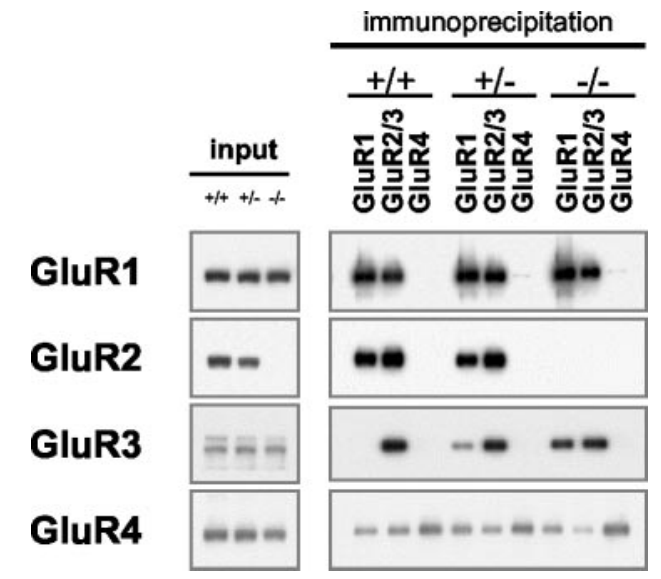

Figure 2. Immunoprecipitation of AMPAR subunits (bound fraction). Ten microliters of bound immunoprecipitate fractions was separated by SDS-PAGE, immunoblotted, and incubated with the indicated C terminus polyclonal antibodies.

one-half of the remaining GluR1 is homomeric. Interestingly, in the GluR2 ${ }^{+1-},>40 \%$ of GluR1 is homomeric compared with $24 \%$ in the GluR2 ${ }^{+/+}$. We were unable to detect $(<5 \%$ of the total) GluR3 homomeric receptor in the GluR2 ${ }^{+/+}$mice (data not shown), but $\sim 25 \%$ of GluR3 is homomeric in the GluR2 ${ }^{-1-}$ mice. Together, these results suggest that formation of the GluR1-R3 complex or homomeric GluR1 or GluR3 is related to the amount of GluR2 available.

\section{Effect of GluR2 deletion on the cellular distribution of AMPA receptors}

It has been shown that AMPAR currents at synapses in the hippocampus of GluR2 ${ }^{-/-}$mice are significantly reduced, suggesting that fewer AMPARs are present at the postsynaptic membrane (Jia et al., 1996). This could be attributable to the reduction in total AMPAR subunits, resulting from the deletion of GluR2 or a less efficient assembly and synaptic delivery of the remaining subunits. Using subunit-specific antibodies and immunogold localization, we analyzed the distribution of the remaining subunits. Ultrastructure of the CA1 and CA3 regions of the hippocampus appeared similar in the GluR2 ${ }^{+/+}$and the GluR2 $2^{-1-}$ animals (Fig. 4). Immunogold analysis was performed on synapses in the CA1 stratum radiatum. Immunogold labeling for GluR2 showed that it was present in the GluR2 ${ }^{+/+}$mice and absent in the GluR2 ${ }^{-1-}$ mice as expected (Fig. 4E; Table 1). Labeling with antibody to GluR2/3 in the GluR2 $2^{-1-}$ mice was reduced to $\sim 15 \%$ of the GluR $2^{+/+}$mice (Fig. $4 A, E$; Table 1 ). In comparison, GluR3 labeling in the GluR2 ${ }^{-l-}$ mice was reduced to only $\sim 70 \%$ of that in the GluR $2^{+/+}$mice; similar results were obtained using two different concentrations of the GluR3 antibody (Fig. 4C,E; Table 1). This suggests that the large decrease in GluR2/3 antibody labeling was attributable to the loss of GluR2 and a small but significant decrease in GluR3, and that the GluR2 $^{+/+}$synapse has more GluR2 than GluR3. The latter suggestion is consistent with previous studies showing that these neurons contain more mRNA for GluR2 than GluR3 (Geiger et al., 1995; Tsuzuki et al., 2001). Similar to GluR3, synaptic GluR1 labeling in the GluR2 ${ }^{-1-}$ mice was reduced significantly, to $\sim 60 \%$ of that in the GluR2 ${ }^{+/+}$mice (Fig. 4 B, E; Table 1). Double labeling with GluR1 and GluR3 showed that these subunits could be colocalized in synapses in both GluR2 $2^{+/+}$and GluR2 ${ }^{-/-}$mice (Fig. 4D). As expected, labeling for GluR4 was very low in both GluR2 $^{+/+}$and GluR2 $2^{-1-}$ mice and was not quantified. Thus,
GluR2 is absent in synapses in GluR2 $2^{-/-}$mice, and the other common subunits, GluR1 and GluR3, are reduced compared with those in the GluR2 ${ }^{+/+}$mice.

Synapses on dendrite shafts made up only a small percentage of the total synapses counted above and often showed high levels of labeling for GluR2/3 in the GluR2 ${ }^{-1-}$ mice, comparable with levels seen in the GluR2 ${ }^{+/+}$mice (Fig. 5). Labeling of dendrite shaft synapses could not be quantified because of the low numbers of these synapses. Double labeling with GluR1 and GluR3 showed that these subunits could be colocalized in these synapses (data not shown). These data suggest that AMPARs on some dendrite shaft synapses, which are found on interneurons, have little or no GluR2 in the GluR2 ${ }^{+/+}$mice, as suggested from previous rat studies (Petralia et al., 1997; Tsuzuki et al., 2001), and thus change little in the GluR2 $2^{-1-}$ mice.

\section{Post-translational processing of AMPARs in GluR2 ${ }^{-/-}$mice}

Although the amounts of the remaining subunits did not change in the GluR2 $2^{-1-}$ mice, our ultrastructural analyses showed that these subunits are less abundant at synapses, suggesting that the remaining subunits are less efficiently delivered to, or retained at, the synapse. A recent study suggests that a large fraction of GluR2 is retained in the endoplasmic reticulum (ER) and thus could be a critical component in the formation of heteromeric complexes and the retention and release of other subunits from the ER (Greger et al., 2002). The remaining subunits may be retained in the ER because of the absence of their favored assembly partner, GluR2. To address this, we analyzed the glycosylation states of GluR1 and GluR3 in the GluR2 ${ }^{+/+}$and GluR2 ${ }^{-1-}$ mice. Membrane homogenates of the hippocampus from GluR2 ${ }^{+/+}$and GluR2 ${ }^{-1-}$ mice were analyzed by Western blotting after denaturation and treatment with endoglycosidase $\mathrm{H}$ (Endo-H) or $N$-glycosidase F (PNGaseF), which enzymatically removes all $\mathrm{N}$-linked carbohydrates. Treatment with Endo-H showed that all four subunits are to some extent Endo-H sensitive. This was particularly apparent for GluR2 in the GluR2 ${ }^{+/+}$mice, which contained an Endo-H-sensitive population that comigrated with completely deglycosylated protein obtained by treating with PNGaseF (Fig. 6A). The Endo-H component was a relatively small percentage of the total GluR2, as previously reported for GluR2 in the rat (Sans et al., 2001). For GluR1 and GluR3 subunits, the same treatment resulted in the appearance of lower molecular weight bands that migrated at intermediate positions as well as a small proportion that migrated at the level of the completely deglycosylated subunit. The presence of an intermediate band is consistent with some glycosyl residues remaining Endo-H sensitive after they exit the ER, whereas the lower band, which comigrated with PNGaseF-treated subunits, represents the GluR1 or GluR3 retained in the ER. In support of this interpretation, the lower band is significantly enriched in intracellular membrane preparations, whereas the intermediate band is enriched in plasma membrane preparations (Sans et al., 2001). No differences in the migration properties of Endo-H-treated GluR1 and GluR3 were apparent for the GluR2 ${ }^{+/+}$and GluR2 ${ }^{-/-}$mice, suggesting that subunits are processed similarly in the GluR2 ${ }^{+/+}$ and GluR2 ${ }^{-1-}$ mice. To support these results, we looked at the GluR1 labeling in the cell body (Fig. $6 B, C, D, G, H$ ) and dendrites (Fig. $6 B, E, F, I, J)$ at the ultrastructural level. In contrast to synapse labeling in the CA1 stratum radiatum, GluR1 labeling in the cell body and apical dendrites of the CA1 pyramidal cells was similar in GluR2 ${ }^{+/+}$and GluR2 ${ }^{-/-}$mice (Fig. $6 B-J$ ). These results are consistent with the results of our Western blots that showed no difference in GluR1 and GluR3 expression in the 
$\operatorname{GluR2}^{+/+}$

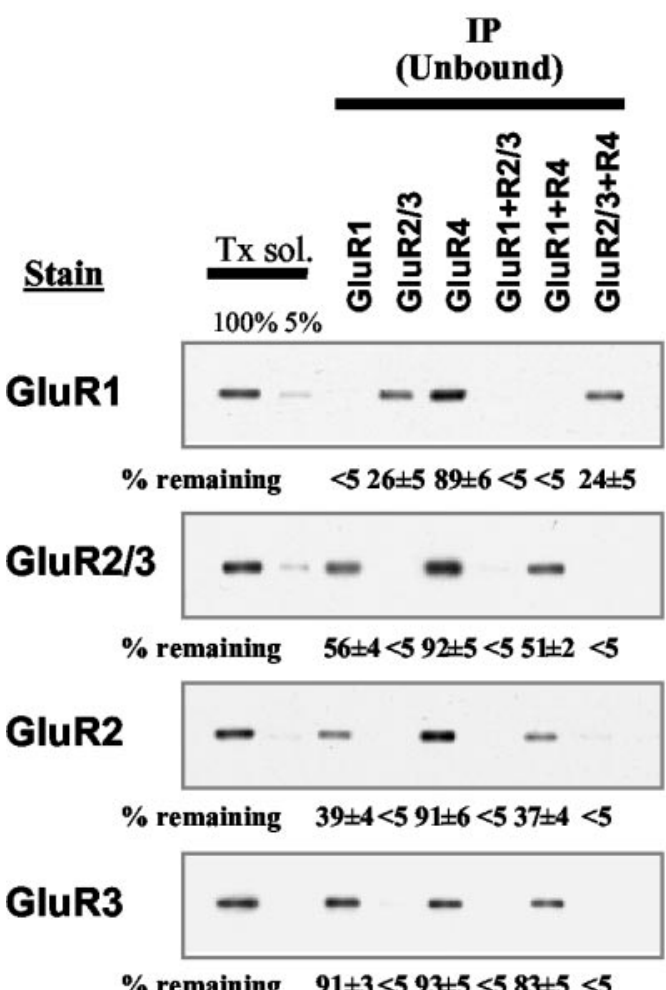

GluR2 $^{+/-}$

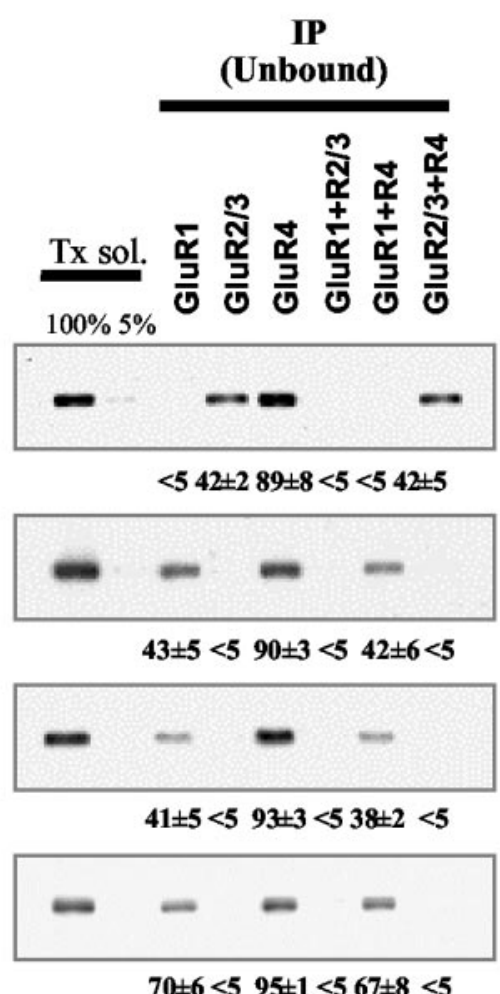

GluR2 $^{-/-}$

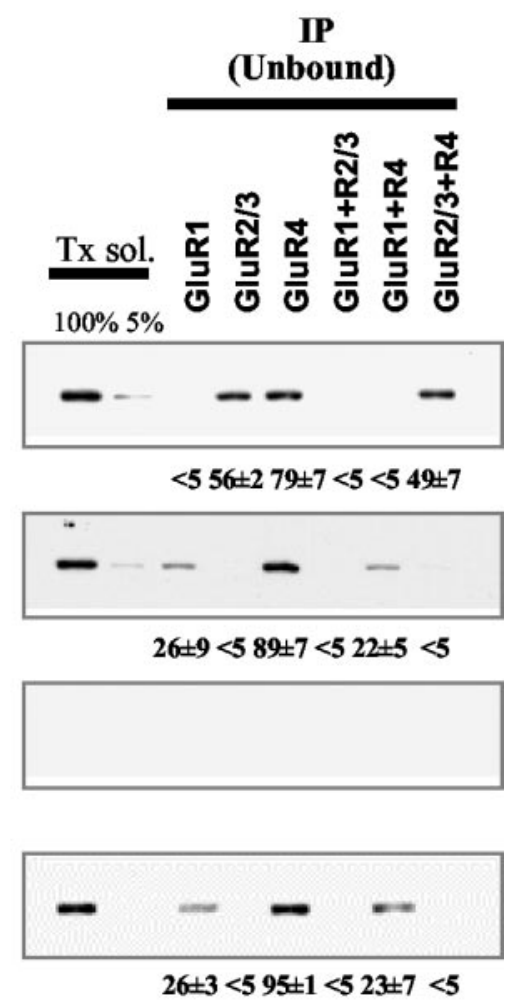

Figure 3. AMPAR subunits remaining (unbound fraction) after immunoprecipitation of detergent-solubilized hippocampal neurons from GluR2 ${ }^{+/+}, \mathrm{GluR2}^{+/-}$, and GluR2 ${ }^{-/-}$mice. The tw0 left lanes of each panel show the nonimmunoprecipitated Triton-solubilized fraction (Tx sol). The $100 \%$ lane represents $10 \mu$ lof sample applied, whereas the $5 \%$ lane represents $0.5 \mu$ l of sample applied (after 1:10 dilution with sample buffer). These lanes represent the range of labeling for quantification of immunoreactivity in the depleted fractions. For each gel, standards of $75,50,25$, and $10 \%$ of the solubilized fraction were also analyzed (data not shown). To determine the amount of immunoprecipitated proteins, after GluR1, GluR2-R3, GluR4, GluR1 plus GluR2-R3, GluR1 plus GluR4, and GluR2-R3 plus GluR4 immunoprecipitation (as indicated on top), $10 \mu$ l of the depleted fraction was analyzed, equivalent to an equal volume of the solubilized fraction (100\%). The percentage of immunostaining remaining in the depleted fractions is shown below each band (mean \pm SEM of three separate experiments).

GluR2 $^{-/-}$mice and with our Endo-H treatment showing again no difference between the GluR2 $2^{+1+}$ and GluR2 ${ }^{-1-}$ mice. Together, these data suggest that the reduction in synaptic receptors is not a result of increased retention in the ER.

\section{Discussion}

In the present study, we investigated AMPAR subunit assembly in the hippocampus using mice with reduced $(+/-)$ or deleted $(-/-)$ GluR2 subunit. In the absence of GluR2, two major changes were observed. First, aberrant receptor complexes comprised of GluR1 and GluR3 were formed. In addition, there was an increased number of homomeric GluR1 and GluR3 receptors. Second, the remaining subunits present as a combination of homomeric and heteromeric receptors made up of GluR1 and GluR3 were less efficiently expressed at the synapse. These results demonstrate that GluR2 is the preferred subunit in the assembly process and indicate a critical role for the GluR2 subunit in both subunit assembly and synaptic expression of AMPA receptors.

Although not completely resolved, results of recent studies tend to support a tetrameric AMPAR complex (Rosenmund et al., 1998; Mansour et al., 2001; Ayalon et al., 2001). Using heterologous cells expressing GluR1 and GluR2, Mansour et al. (2001) showed that the preferred assembly pattern yields a maximum of two different subunits per tetrameric complex, presenting a stoichiometry of 2:2. This could be achieved by initial formation of heterodimers followed by the combination of like pairs of dimers. Our results are consistent with such a model. In the GluR2 ${ }^{+/+}$ animal, most receptors are GluR1-R2 and GluR2-R3 with a small amount of homomeric GluR1 and no detectable homomeric GluR3. The absence of GluR1-R3 receptors in hippocampal pyramidal neurons could be simply because of the inability of GluR1 and GluR3 to assemble with one another. However, GluR1 and GluR3 can assemble in heterologous cells (Sekiguchi et al., 1994), suggesting that their failure to assemble in hippocampal neurons is not because of an innate property of the subunits. The explanation most consistent with these results is that both GluR1 and GluR3 have a greater capacity to assemble with GluR2 than with each other or themselves. GluR1-R3 complexes are present only when the amount of GluR2 is reduced. Thus, GluR2 plays a critical role in assembly in neurons by being the preferred partner for both GluR1 and GluR3, such that GluR1-R3 complexes are not formed in the presence of sufficient GluR2. Even in the absence of GluR2, the formation of GluR1-R3 complexes is not maximal with much GluR1 and GluR3 forming homomeric receptors. Therefore, the tendency to form GluR1-R3 complexes is similar to that of forming homomeric receptors, which in the case of GluR1 and GluR2 is less preferred than the formation of heteromeric complexes (Mansour et al., 2001). The preferred assembly of GluR2 with GluR1 or GluR3 could be achieved if the initial interaction has a higher affinity for GluR2. Alternatively, the stability of the intermediate subunit dimer could control the nature of the final complex. In addition to generating two distinct classes of AMPARs, GluR1-R2 and GluR2-R3, such a mechanism would 
also ensure that most receptors would contain GluR2 and thus be calcium impermeable.

The relative abundance of AMPAR subunits in hippocampal neurons is unknown, but single-cell PCR has been used to quantify the amount of mRNA for these subunits in CA3 pyramidal neurons in slices from 12- to 17-d-old rats (Geiger et al., 1995) and in pyramidal neurons of 9-d-old cultured neurons (Tsuzuki et al., 2001). These results both show nearly equal amounts of GluR1 and GluR2 mRNA but less than one-tenth of these amounts for GluR3 and even less GluR4. The small amount of GluR3 fits our observations using the GluR2/3 antibody in the GluR2 $^{-1-}$ mice, which showed only $\sim 15 \%$ of the labeling seen in the GluR2 ${ }^{+/+}$. Although mRNA levels cannot be used to accurately or reliably project relative amounts of proteins, our studies tend to support the conclusion that GluR1 and GluR2 are the predominant subunits in hippocampal pyramidal neurons, and that GluR3 is present in somewhat less abundance, whereas GluR4 is very low. This relative abundance of the subunits would also fit our conclusion that GluR1 and GluR3 favor assemblies with GluR2. With GluR3 present in amounts much less than those of GluR1 and with assembly efficiencies of GluR2 similar to those of GluR1, very little homomeric GluR3 would be present. In contrast, the more abundant GluR1 would have a larger homomeric pool. Our results also suggest that an increase in the production of GluR2 would lead to more GluR1-R2 complexes and a reduction in homomeric GluR1.

A previous study (Jia et al., 1996) showed a $>50 \%$ reduction in AMPA current amplitudes relative to NMDA currents in CA1 neurons of GluR2 $2^{-1-}$ mice. Our results suggest that this is because of both the loss of a prominent synaptic AMPAR subunit, GluR2, as well as a less efficient synaptic expression of the major remaining subunits GluR1 and GluR3. Although homomeric GluR1 receptors represent a significant subset of AMPARs and may be particularly abundant in interneurons, GluR3 homomeric receptors and GluR1-R3 heteromeric receptors have not been identified in neurons. Inefficient trafficking or decreased synaptic retention of these complexes may therefore explain the reduced synaptic immunolabeling that we observed. However, the abundant immunogold labeling that we obtained for both GluR1 and GluR3 associated with shaft synapses on interneurons would suggest that this is not the case, at least in interneurons.

One of the most interesting aspects of our findings is that the availability of the GluR2 subunit is a major determinant in the composition of AMPARs in pyramidal neurons and indirectly plays a role in the trafficking of receptors to the synapse. This introduces an additional level of plasticity associated with the receptor population that will ultimately impact the composition and number of synaptic receptors. This is particularly important for GluR2, because the synthesis of this subunit has been reported to be altered under pathological conditions, including ischemia

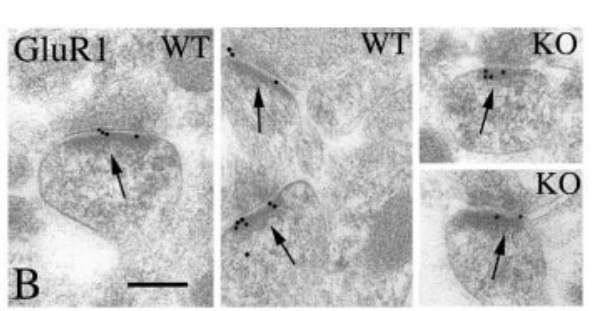

GluR1 (10)+ GluR3 (5)

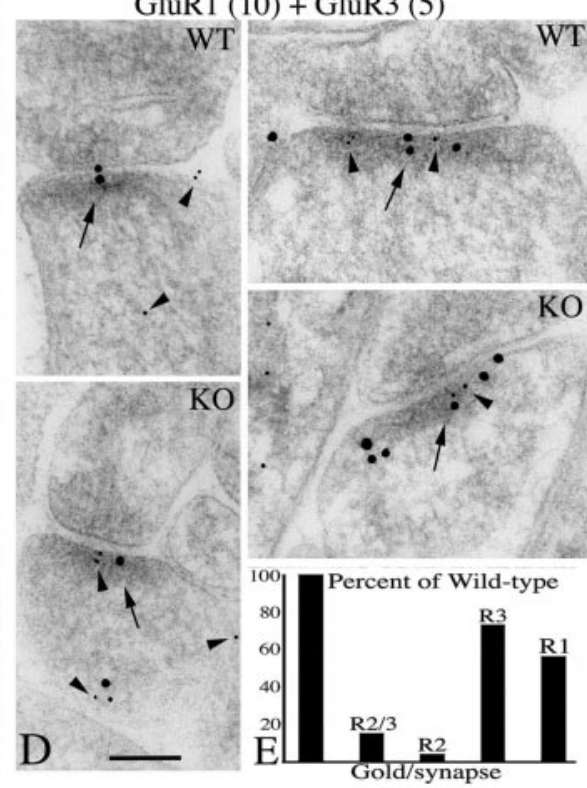

Figure 4. $A, B, C$, Immunogold localization of AMPARs in the CA1 stratum radiatum of $\mathrm{GluR2}^{+/+}$(WT) and GluR2 ${ }^{-1-}$ (K0) mice, using GluR2-R3 $(A)$, GluR1 ( $B)$, and GluR3 ( $C$ antibodies. Note that in these micrographs, there is less gold labeling in GluR2 ${ }^{-1-}$ than in GluR2 ${ }^{+/+}$mice. D, Double labeling for GluR1 (10 nm gold particles) and GluR3 (5 nm gold particles). bars: $A-C, 200 \mathrm{~nm} ; D, 100 \mathrm{~nm}$. E, Quantification of gold labeling for gold per synapse using GluR2/3, GluR2, GluR3, and GluR1 mice, relative to $\mathrm{GluR2}^{+/+}$mice.

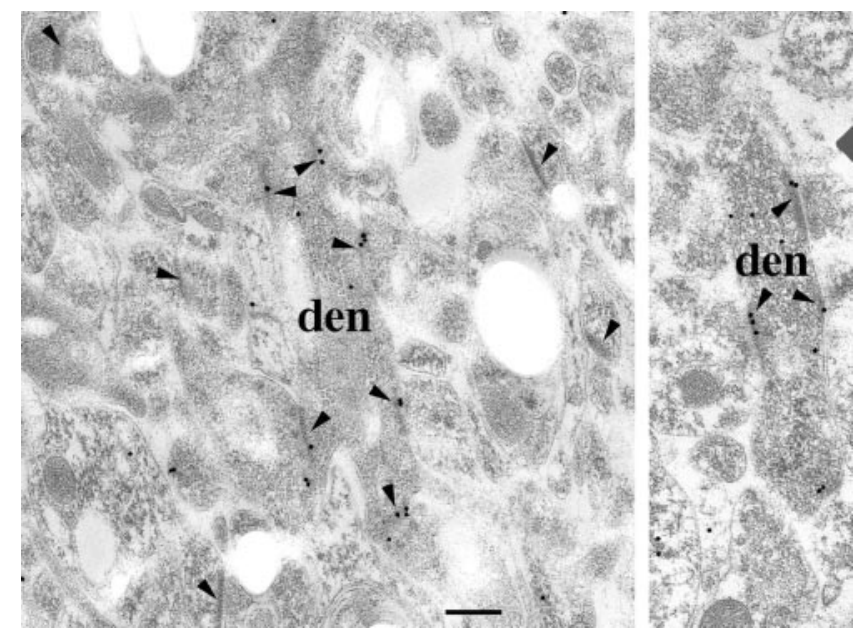

Figure 5. Immunogold localization with GluR2/3 antibody on interneuron synapses [i.e., found on a dendrite shaft (den), compared with spine synapses, in two GluR2 ${ }^{-1-}$ animals]. Arrowheads indicate postsynaptic labeling. Note that the labeling is prevalent in the dendrite shaft synapses but not in the spine synapses. Scale bar, $200 \mathrm{~nm}$.

(Opitz et al., 2000), trauma (Grossman et al., 1999), and hypoxia (Sanchez et al., 2001). The significant reduction in the level of GluR2 protein reported in some cases (e.g., 50\% in ischemia) is similar to the reduction we found in GluR2 ${ }^{+/-}$animals, suggest- 
A

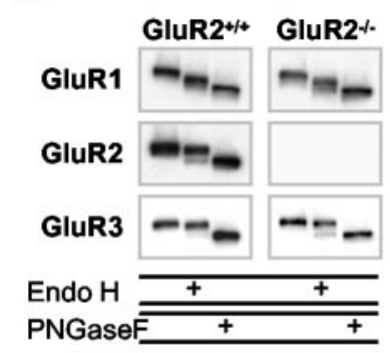

GluR2 $^{+/+}$

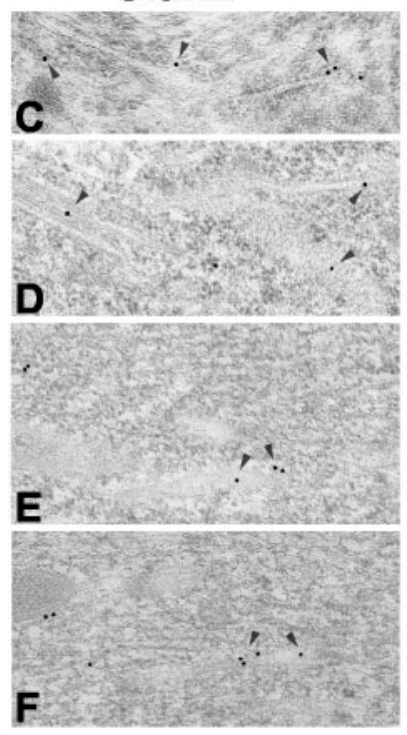

B

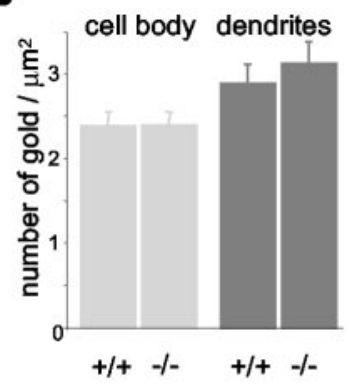

GluR2-1-

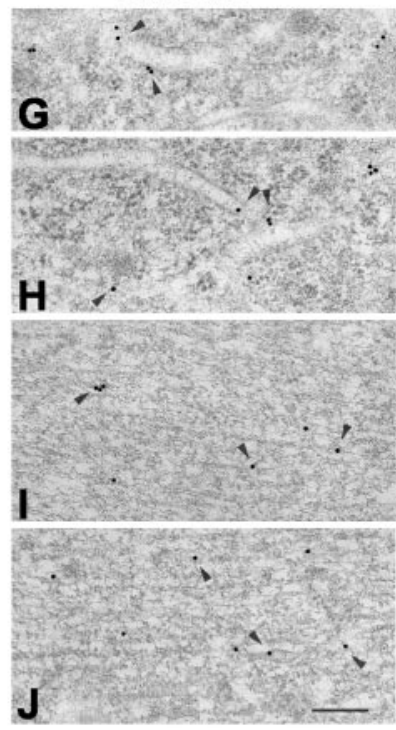

Figure 6. Intracellular receptors in GluR2 $2^{+/+}$and GluR2 ${ }^{-1-}$ mice. $A$, Glycosylation state of AMPARs in the GluR2 ${ }^{+/+}$and GluR2 ${ }^{-1-}$ mice. Membrane homogenates from the hippocampus of GluR2 ${ }^{+/+}$and GluR2 ${ }^{-1-}$ mice were solubilized with $0.5 \%$ SDS in the presence of $1 \%$ $\beta$-mercaptoethanol. After dilution with $1 \% \mathrm{NP}-40$, soluble extracts were incubated in the absence of enzyme (control samples) or in the presence of Endo-H or PNGaseF. GluR1 and GluR3 have a small but distinct population that is Endo-H sensitive in the GluR2 ${ }^{+/+}$and GluR2 ${ }^{-1-}$ mice. B, Quantification of gold labeling per square micrometer using GluR1 antibody in the cell body (light gray; $n=38$ for GluR2 ${ }^{+/+} ; n=35$ for GluR2 ${ }^{-1-} ; p=0.96$ ) and dendrites (dark gray; $n=21$ for GluR2 ${ }^{+/+} ; n=17$ for GluR2 $\left.{ }^{-1-} ; p=0.50\right)$ of GluR2 ${ }^{+/+}$and GluR2 ${ }^{-1-}$ mice. $\left(-J\right.$, Representative micrographs of GluR1 labeling in the cell body of $G$ luR2 ${ }^{+/+}(C, D)$ and $\mathrm{GluR2}^{-I-}(G, H)$ mice and in dendrites of GluR2 ${ }^{+/+}(E, F)$ and GluR2 ${ }^{-I-}(I, J)$ mice. Arrowheads indicate labeling associated with ER or reticular-like structures. Scale bar, $200 \mathrm{~nm}$.

ing that, under certain conditions, an increase in GluR1-R3 complexes and GluR1 and GluR3 homomeric complexes is occurring. Not only is a larger population of calcium-permeable AMPARs generated, but also our findings suggest that the trafficking of the new complexes would differ.

\section{References}

Ayalon G, Stern-Bach Y (2001) Functional assembly of AMPA and kainate receptors is mediated by several discrete protein-protein interactions. Neuron 31:103-113.

Dingledine R, Borges K, Bowie D, Traynelis SF (1999) The glutamate receptor ion channels. Pharmacol Rev 51:7-61.

Geiger JR, Melcher T, Koh DS, Sakmann B, Seeburg PH, Jonas P, Monyer H (1995) Relative abundance of subunit mRNAs determines gating and $\mathrm{Ca}^{2+}$ permeability of AMPARs in principal neurons and interneurons in rat CNS. Neuron 15:193-204.

Greger IH, Khatri L, Ziff EB (2002) RNA editing at arg607 controls AMPAR exit from the endoplasmic reticulum. Neuron 34:759-772.

Grossman SD, Wolfe BB, Yasuda RP, Wrathall JR (1999) Alterations in AMPAR subunit expression after experimental spinal cord contusion injury. J Neurosci 19:5711-5720.

Henley JM (2003) Proteins interactions implicated in AMPA receptor trafficking: a clear destination and an improving route map. Neurosci Res 45:243-254.

Hollmann M, Heinemann S (1994) Cloned glutamate receptors. Annu Rev Neurosci 17:31-108.

Jia Z, Agopyan N, Miu P, Xiong Z, Henderson J, Gerlai R, Taverna FA, Velumian A, MacDonald J, Carlen P, Abramow-Newerly W, Roder J (1996) Enhanced LTP in mice deficient in the AMPAR GluR2. Neuron 17:945-956.

Malinow R, Malenka RC (2002) AMPAR trafficking and synaptic plasticity. Annu Rev Neurosci 25:103-126.

Malinow R, Mainen ZF, Hayashi Y (2000) LTP mechanisms: from silence to four-lane traffic. Curr Opin Neurobiol 10:352-357.

Mano I, Teichberg VI (1998) A tetrameric subunit stoichiometry for a glutamate receptor-channel complex. NeuroReport 9:327-331.

Mansour M, Nagarajan N, Nehring RB, Clements JD, Rosenmund C (2001) Heteromeric AMPAR assemble with a preferred subunit stoichiometry and spatial arrangement. Neuron 32:841-853.

Moga DE, Janssen WGM, Vissavajjhala P, Czelusniak SM, Moran TM, Hof PR, Morrison JH (2003) GluR3 immunoreactivity delineates a subpopulation of parvalbumin-containing interneurons in the rat hippocampus. J Comp Neurol 462:15-28.

O'Gorman S, Dagenais NA, Qian M, Marchuk Y (1997) Protamine-Cre recombinase transgenes efficiently recombine target sequences in the male germ line of mice, but not in embryonic stem cells. Proc Natl Acad Sci USA 94:14602-14607.

Opitz T, Grooms SY, Bennett MV, Zukin RS, Optiz T (2000) Remodeling of AMPA subunit composition in hippocampal neurons after global ischemia. Proc Natl Acad Sci USA 97:13360-13365.

Petralia RS, Wang YX, Mayat E, Wenthold RJ (1997) GluR2-selective antibody shows a differential distribution of calcium-impermeable AMPARs among populations of neurons. J Comp Neurol 385:456-476.

Robertson EJ (1987) Embryo-derived stem cell lines. In: Teratocarcinomas and embryonic stem cells: a practical approach (Robertson EJ, ed), pp 71-112. Oxford: IRL.

Rosenmund C, Stern-Bach Y, Stevens CF (1998) The tetrameric structure of a glutamate receptor channel. Science 280:1596-1599.

Sanchez RM, Koh S, Rio C, Wang C, Lamperti ED, Sharma D, Corfas G, Jensen FE (2001) Decreased GluR2 expression and enhanced epileptogenesis in immature rat hippocampus after perinatal hypoxia-induced seizures. J Neurosci 21:8154-8163.

Sans N, Petralia RS, Wang Y-X, Blahos II J, Hell JW, Wenthold RJ (2000) A developmental change in NMDA receptor-associated proteins at hippocampal synapses. J Neurosci 20:1260-1271.

Sans N, Racca C, Petralia RS, Wang Y-X, McCallum J, Wenthold RJ (2001) Synapse-associated protein 97 selectively associates with a subset of AMPA receptors early in their biosynthetic pathway. J Neurosci 21:7506-7516.

Sekiguchi M, Doi K, Zhu WS, Watase K, Yokotani N, Wada K, Wenthold RJ (1994) A deletion in the second cytoplasmic loop of GluR3 produces a dominant negative mutant of AMPAR. J Biol Chem 269:14559-14565.

Shi SH, Hayashi Y, Petralia RS, Zaman SH, Wenthold RJ, Svoboda K, Malinow R (1999) Rapid spine delivery and redistribution of AMPARs after synaptic NMDAR activation. Science 284:1811-1816.

Tanaka H, Grooms SY, Bennett MV, Zukin RS (2000) The AMPAR subunit GluR2: still front and center-stage. Brain Res 886:190-207.

Tsuzuki K, Lambolez B, Rossier J, Ozawa S (2001) Absolute quantification of AMPAR subunit mRNAs in single hippocampal neurons. J Neurochem $77: 1650-1659$.

Wenthold RJ, Yokotani N, Doi K, Wada K (1992) Immunochemical characterization of the non-NMDAR using subunit-specific antibodies. Evidence for a hetero-oligomeric structure in rat brain. J Biol Chem 267:501-507.

Wenthold RJ, Petralia RS, Blahos II J, Niedzielski AS (1996) Evidence for multiple AMPAR complexes in hippocampal CA1/CA2 neurons. J Neurosci 16:1982-1989. 